\title{
Development Strategy of Noken Product on Local Community in Sota Merauke
}

\section{Semuel Batlajery ${ }^{1 *}$, Caecilia Heny Setya Wati ${ }^{2}$}

1,2 Musamus University, Merauke

\section{A R T I C L E I N F 0}

Article history:

Received 19 February 2019

Received in revised form

16 March 2019

Accepted 15 April 2019

Available online 26 May

2019

Keywords:

Development Product,

SWOT

\section{A B S T R A C T}

This research aims to formulate Strategy development product Noken of to local community of district border of Merauke / Papua New Guinea. The method used is the observation and in-depth interview on noken craftsmen. The formulation of appropriate strategies for local communities Noken craftsmen are essential for business continuity and profit in business competition. Increasingly tight competition required the noken craftsmen to always do the strategy in developing noken products well.Moreover, neighboring Papua New Guinea's noken products are always flooding the sota border areas.Analysis SWOT shows that the position of noken craftsmen in the tourist area means the situation is very profitable.Craftsmen have the opportunity and power so as to harness the power to redeem opportunities.

\footnotetext{
* Corresponding author.

E-mail addresses: batlajerys1@gmail.com (Semuel Batlajery)
} 


\section{Introduction}

In the midst of an increasingly competition which getting more competitive situation that characterized by the increasing number of players and increasing in high market demands, a company can no longer only rely on easily accessible locations, easily available raw materials or the availability of access to capital, but also the ability to produce more quality and innovative products. Companies are required to have sufficient knowledge resources, from knowledge of process technology, markets and marketing, business development and other knowledge areas according to company needs. Nonaka and Takeuchi (1995) also emphasize that currently companies that want to succeed are those who consistently create new knowledge, spread it widely within organizations, and quickly turn it into a variety of new technologies and products.

In developing new products, the first step is to survey the characteristics of customers who buy the products offered. Customers are grouped by sex, age, occupation, income, education, and others. Knowledge of these customers, can help companies in making new product development decisions. New products include (new-to-the-world) products that create new markets, minor product developments, and revisions to existing products (Kotler, 2009). Booz, Allen \& Hamilton in Kotler (2000) identified that there are six new product categories, namely: 1) New products with the creation of new markets (new to the world products), 2) New products by first entering the existing market for new products (new product lines), 3) New produc fromt modified older products (additions to existing product lines), 4) New products to replace existing products for performance and value (improvements and revisions to existing products), 5) Existing products targeted at new markets or new segments (repositionings), and 6) New products at lower prices (cost reductions)

The phenomenon of changing needs and lifestyles caused by this age development has spurred companies as producers to continue in innovating. Old products are constantly being redesigned, and new products are constantly being developed (Handoko, 2000: 32). The company seeks to offer its products so that consumers are interested and make purchases. Thus, companies must compete by mastering technology to prepare themselves for product innovation. The most important innovation that can be done by the company is the renewal concerning the product itself, because the product is the main reason for someone to choose and buy it.

Consumers will make a decision to buy a product if the product has more value than other products. To create products that have sales value and competitiveness, in the innovation process companies must be able to create the right business strategy. Therefore, companies need to utilize their resources optimally and carry out product development activities to keep the company survive. Development and design of good quality products is the key to success in the business world.

According to Kotler and Keller (2009: 374), companies must develop new products. New product development shapes the future of the company. Replacement products must be created to maintain or build sales. Companies can add new products through the acquisition and / or development of new products. The purpose of developing new products is to implement product strategies that are in line with market demand with competitive advantages.

Noken is a hanging bag that is produced or produced by the local Papuan community with a traditional production method. The problems that occur are the products produced were far from what is expected by consumers, so sometimes the goods are not sold. Based on the results of observations made that it turns out that the Noken craftsmen in this case are the Papuan Local people who live in the village of Sota (border with Papua New Guinea) in Merauke Regency, still have many shortcomings in terms of model, capital, and marketing. However, as a home industry they must also keep abreast of developments and require innovation and product development, so that companies can survive or develop and compete with other companies.

Based on the above background, the research problem can be formulated as follows: "What are the product development strategies that can be done so that the Noken product craftsmen industry can survive amidst fierce competition with similar products".

Based on the Background and the formulation of the problems that have been raised, this study was designed with the aim of: "To find out what product development strategies can be done so that the Noken product craftsmen industry can survive amidst fierce competition with similar products". 


\section{Methods}

This research was carried out in the Sota Local Community in Merauke district, this research was carried out from January 2017 to December 2018.

Research Methodolgy

The approach used in this study is qualitative research with the following methods :

Primary Data :

Direct observation data in the field, interviews, giving questionnaires to owners and managers of noken businesses to identify internal and external factors that influence company performance, as well as determining value and ratings for each of these factors.

Socondary Data

Data collected through literature studies and statistical data that relevant to this research.

A. Research Informants

The population in this study was determined by Purposive Sampling that is by using sampling techniques with certain considerations. In this case the selection of respondents was deliberately chosen by the researcher. Respondents in this study were noken craftsmen with a total of 10 respondents who knew the best for their business both from internal and external factors. Informant details as follows:
1. Noken Craftsmen : 6 orang
2. Society : 4 orang
B. Data Collection Techniques
1. Obervation

What is done on all aspects of business management, finance, production and Human Resource..

2. In-depth interviews with informants from :

a) Society, to get an idea of the business conditions and challenges faced by these craftsmen..

b) Collectors, to get an idea of the size of market demand and strategic issues in the field of marketing and sales.

c) Product design consultant, to find out the possibilities for developing skin-based product designs.

3. Discussion, is to conduct interviews and exchange ideas about the problems and conditions that occur in noken craftsmen.

4. The questionnaire is to give a statement in the form of a questionnaire to the selected respondents to provide answers regarding the inernal and external factors of the noken craftsman.

5. Focus Group Discussion (FGD) was conducted to support the preparation of the SWOT analysis.

6. Secondary data (published and unpublished) about: competitive situations in the leather craft industry, regulations in the field of MSMEs, and other relevant data.

Scales Measurement

1. Give an assessment (in column 3) for each factor by providing a scale ranging from 4 (outstanding) to 1 (poor), based on the influence of these factors on the condition of the company concerned. Giving a rating of strength in the IFE matrix with a scale used, which are: 1 = very weak, 2 = weak, 3 = strong, 4 $=$ very strong. As for the factors that are the weakness of giving rating values will be done in the opposite way.

2. Giving the opportunity rating value on the EFE matrix with the scale used, started from: $1=$ low (response less), 2 = moderate (response equal to average), $3=$ high (response above average), and $4=$ very high ( response above average). As for the factors that become a threat, giving a rating value wil be done otherwise. Multiply each value (column 2) by rating column 3 to obtain the rating factor (column 4). The result is an assessment score for each factor whose value varies, starting at 4.00 (outstanding) up to 0.0 (poor).

Processing and Analysis of Internal Data

1. Internal External Matrix (IE)

After the IFE and EFE matrices are made, the next step is to compile the IE Matrix which is a mapping of the IFE and EFE matrix total scores generated from the company's external and internal audits (David, 2002).

2. External Factor Evaluation (EFE) and Internal Factor Evaluation (IFE) Matrix The EFE matrix is used to analyze external factors for opportunities and threats and then do an assessment. The IFE matrix is used to analyze internal factors for strengths and weaknesses and then conduct an assessment (David, 2006)

According to Kinnear (2006), the weight of each variable is obtained by determining the value of each variable to the total value of the variables using the formula: 


$$
\alpha \mathrm{i}=\frac{X i}{\sum_{i=1}^{n} \mathrm{Xi}}
$$

Where: $\alpha \mathrm{i}=\mathrm{i}-\mathrm{i}$ variable weight

$\mathrm{Xi}=$ the value of the $\mathrm{i}$-variable

I $=1,2,3, \mathrm{n}$

$\mathrm{n} \quad$ number of variables

Data Analysis Method

The method used in this study is: SWOT Analysis which consists of strengths (strengths) and weaknesses (weaknesses), opportunities (opportunities) and threats (threats) in an environment faced by an organization or company. SWOT analysis is a systematic way to identify these factors and strategies that describe the best compatibility between them (Pearce and Robinson, 2006).

\section{Result and Discussion}

General Description of Sota District

Sota Village is one of the Local Villages located in Sota District, Merauke Regency. Sota village has borders or regional boundaries as follows:

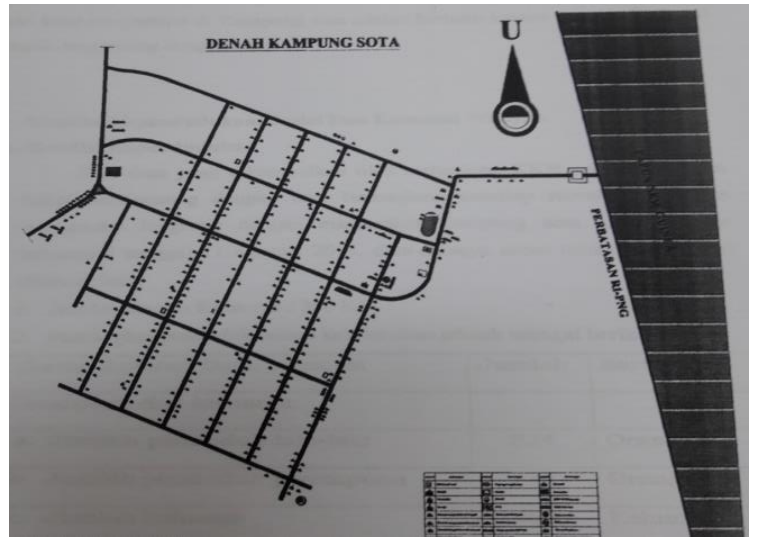

Picture 1. Scetch Picture of Sota Village

Where:

1. North side borders: Erambo Village

2. East side borders: PNG country

3. South side borders: Yanggandur village

4. West side borders: Wasur National Park

The latest data in August 2016 in Sota Village consisted of 11 RTs and 3 RKs, with a total of 360 families, with a population of 1600 , with 824 men and 776 women.. One characteristic of the community in Sota Village is hunting because local people are still depend on nature.

Description of Respondents

Tabel 1. Characteristics of Informants by Gender

\begin{tabular}{cllcc}
\hline No. & & Gender & Total & Percentage $\%$ \\
\hline 1 & Male & & 3 & 30 \\
2 & Female & & 7 & 70 \\
\hline & Total & 10 & 100 \\
\hline
\end{tabular}

From the table above shows that the respondents are noken craftsmen. The dominating respondents were 7 females with a percentage (70\%) and a male that consists of 3 people $(30 \%)$. This shows that noken craftsmen are more dominated by women than men, indicating that women are equal to men. 
Tabel 2. Informants Caharateristics Based on Age

\begin{tabular}{cccc}
\hline No. & Gender & Total & Percentage $\%$ \\
\hline 1 & $21-30$ Age & 3 & 30 \\
2 & $31-40$ Age & 5 & 50 \\
3 & $41-50$ Age & 1 & 10 \\
4 & $>50$ Age & 1 & 10 \\
\hline & Total & 10 & 100 \\
\hline
\end{tabular}

Based on Table 2 above shows that 10 respondents who were used as informants in research based on age are as follows: respondents aged between 21-30 years amounted to 3 people or 30\%, respondents aged 31 - 40 years amounted to 5 people or 50\%, respondents those aged 41-50 years amounted to 1 person or $10 \%$, respondents aged over 50 years amounted to 1 person or $10 \%$.

a. Internal Environmental Analysis

Inernal environment analysis is a process of identification of the factors that influence the strengths and weaknesses of noken craftsmen in sota. The internal environment of the noken craftsman is analyzed by a functional approach, which consists of marketing, production, human resources, finance, and management that is in the noken craftsman.

The analysis of the noken craftsmen's internal environment includes strengths and weaknesses can be seen in the table below:

Table 3. Strengths and Weaknesses of Noken Craftsmen

\begin{tabular}{|c|c|c|}
\hline Internal Factor & Strenghts & Weaknesses \\
\hline Marketing & $\begin{array}{l}>\text { Sota as a tourist place } \\
\text { Noken craftsmen are in the tourist area }\end{array}$ & $\begin{array}{l}>\text { Not yet doing promotion through } \\
\text { mass media } \\
>\text { There are no interesting images } \\
\text { design on noken products }\end{array}$ \\
\hline Production & $\begin{array}{l}\text { Human resources are adequate } \\
\text { The craftsmen have started to rely on } \\
\text { handicrafts as additional income }\end{array}$ & $\begin{array}{l}>\text { Raw materials are difficult to } \\
\text { obtained } \\
>\text { The craftsmen have not used the } \\
\text { technology for noken production } \\
>\text { Lack of good design on noken } \\
\text { products }\end{array}$ \\
\hline HR & - & $\begin{array}{l}\text { The organization of the noken } \\
\text { craftsman is not yet being } \\
\text { structured } \\
>\text { Craftsmen have not been able to } \\
\text { build communication with } \\
\text { suppliers and administrations } \\
\text { that have not been well organized. } \\
>\text { Noken craftsmen still buying } \\
\text { products from neighboring } \\
\text { countries (PNG) for resale }\end{array}$ \\
\hline Finance & - & $>\begin{array}{l}\text { Limited funds to buy raw } \\
\text { materials }\end{array}$ \\
\hline Management & - & $\begin{array}{l}\text { Coordination between craftsmen } \\
\text { has not been well developed }\end{array}$ \\
\hline
\end{tabular}

b. External Environmental Analysis

The analysis of the external environment of the noken craftsman identifies opportunities and threats which include external factors such as demography, economics, nature, social culture, politics and technology. External environment analysis on noken craftsmen covering opportunities and threats that can be seen in the table below:

Table 4. Opportunities and Threats of Noken Craftsmen 


\begin{tabular}{|c|c|c|}
\hline External factor & Opportunities & Threats \\
\hline Demography & - & $\begin{array}{l}\text { Community income is still low } \\
\text { Community consumption } \\
\text { patterns often change }\end{array}$ \\
\hline Economy & $\begin{array}{l}\text { Good market potential } \\
\text { The high profit obtained from the sale } \\
\text { of noken }\end{array}$ & - \\
\hline Nature & - & $\begin{array}{l}\text { The availability of raw materials } \\
\text { began to decrease }\end{array}$ \\
\hline Socio-cultural & $\begin{array}{l}\text { Availability of craftsmen } \\
\text { The sota community began to make } \\
\text { the creativity of noken craftsmen as } \\
\text { additional income }\end{array}$ & - \\
\hline Political & $\begin{array}{l}\text { The regional government provides } \\
\text { freedom to develop the business. }\end{array}$ & - \\
\hline Technology & - & $\begin{array}{l}\text { The lack of development in terms } \\
\text { of knowledge about craftsmen's } \\
\text { technology }\end{array}$ \\
\hline
\end{tabular}

c. IFE Matrix Analysis

The IFE matrix is used to determine the effect of internal factors of noken craftsmen. The total value assessed in this matrix is the total sum of the multiplication of weights and branches of each of the noken craftsmen's internal strategy factors. Can be seen in the table below:

Table 5. The results of the IFE Matrix analysis

\begin{tabular}{|c|c|c|c|c|}
\hline No. & Strenghts & Value & Rating & Score \\
\hline 1 & Sota as a tourist place & 0,133 & 4,0 & 0,533 \\
\hline 2 & Noken craftsmen are in the tourist area & 0,100 & 3,0 & 0,300 \\
\hline 3 & $\begin{array}{l}\text { Human resources in the making of } \\
\text { noken products }\end{array}$ & 0,100 & 3,0 & 0,300 \\
\hline 4 & $\begin{array}{l}\text { The craftsmen have started to rely on } \\
\text { handicrafts as additional income }\end{array}$ & 0,100 & 3,0 & 0,300 \\
\hline \multicolumn{5}{|c|}{ Weaknesses } \\
\hline 1 & $\begin{array}{l}\text { Not yet doing promotion through mass } \\
\text { media }\end{array}$ & 0,033 & 1,0 & 0,033 \\
\hline 2 & $\begin{array}{l}\text { Not yet designing images on noken } \\
\text { products }\end{array}$ & 0,033 & 1,0 & 0,033 \\
\hline 3 & Raw materials are difficult to obtained & 0,033 & 1,0 & 0,033 \\
\hline 4 & $\begin{array}{l}\text { The craftsmen have not used the } \\
\text { technology for noken production }\end{array}$ & 0,067 & 2,0 & 0,133 \\
\hline 5 & Lack of good design of noken products & 0,067 & 2,0 & 0,133 \\
\hline 6 & $\begin{array}{l}\text { The organization of the noken } \\
\text { craftsman is not yet being structured }\end{array}$ & 0,067 & 2,0 & 0,133 \\
\hline 7 & $\begin{array}{l}\text { Craftsmen have not been able to build } \\
\text { communication with suppliers and } \\
\text { administrations that have not been } \\
\text { well organized. }\end{array}$ & 0,067 & 2,0 & 0,133 \\
\hline 8 & $\begin{array}{l}\text { Noken craftsmen still buying products } \\
\text { from neighboring countries (PNG) for } \\
\text { resale }\end{array}$ & 0,067 & 2,0 & 0,133 \\
\hline 9 & Limited funds to buy raw materials & 0,067 & 2,0 & 0,133 \\
\hline 10 & Coordination between craftsmen has & 0,067 & 2,0 & 0,133 \\
\hline
\end{tabular}


not been well developed

Based on the results of calculations in the IFE matrix table, it was found that the total score reached 2.467. From the total score with this value, it can be concluded that craftsmen have a strategy with a weak internal position, because it is below with a value of 2.50 . This shows that the noken craftsmen have not been able to optimize their strengths and have not been able to overcome the weaknesses. The main strength of the noken craftsman is Sota as a tourist place, with a score of 0.533 . While the main weaknesses of noken craftsmen are as follows: (1), Not yet doing promotion through mass media, (2), Not yet designing images on noken products, (3). Raw materials are difficult to obtained, these three points have the same value, with a score of 0.033 .

d. EFE Matrix Analysis

The EFE matrix is used to determine the effect of external factors of noken craftsmen. The total value assessed in this matrix is the total sum of the multiplication of weights and branches of each of the noken craftsmen's external strategy factors. Can be seen in the table below:

Table 6. The results of the EFE Matrix analysis

\begin{tabular}{clccc}
\hline No. & \multicolumn{1}{c}{ Opportunity } & Value & Rating & Score \\
\hline 1 & Good market potential & 0,154 & 4,0 & 0,615 \\
2 & $\begin{array}{l}\text { The high profit obtained from the sale of } \\
\text { noken }\end{array}$ & 0,115 & 3,0 & 0,346 \\
3 & $\begin{array}{l}\text { Availability of craftsmen } \\
\text { The sota community began to make the } \\
4\end{array}$ & 0,115 & 3,0 & 0,346 \\
& $\begin{array}{l}\text { creativity of noken craftsmen as additional } \\
\text { income }\end{array}$ & 0,115 & 3,0 & 0,346 \\
5 & $\begin{array}{l}\text { The regional government provides freedom } \\
\text { to develop the business }\end{array}$ & 0,154 & 4,0 & 0,615 \\
\hline Threats & & 0,077 & 2,0 & 0,154 \\
\hline 1 & $\begin{array}{l}\text { Community income is still low } \\
\text { Community consumption patterns often } \\
\text { change }\end{array}$ & 0,115 & 3,0 & 0,346 \\
3 & $\begin{array}{l}\text { The availability of raw materials began to } \\
\text { decrease }\end{array}$ & 0,115 & 3,0 & 0,346 \\
4 & $\begin{array}{l}\text { The lack of development in terms of } \\
\text { knowledge about craftsmen's technology }\end{array}$ & 0,038 & 1,0 & 0,038 \\
\hline & $\quad$ EFE Matrix Total Score & 1,000 & 3,154 \\
\hline
\end{tabular}

Based on the results of calculations in the EFE matrix table above, it was found that the total score reached 3.154. This shows that the noken craftsmen are strong in taking advantage of opportunities to overcome threats. The main opportunity for noken craftsmen is the existence of a large market potential and the regional government gives freedom to develop its business, which obtained the score of 0.593 . While the main threat of noken craftsmen is the lack of development of knowledge about craftsmen's technology, in this case it achieved the score of 0.038 .

In general, it can be seen that the EFE factor is better than the IFE factor, this means that the continuity of the craftsmen is mostly determined by the EFE factor. This illustrates that the strategic position of the noken craftsman has not optimized the IFE factor really well, so the craftsmen need to evaluate and improve the situation they faced.

Based on the IFE / EFE Matrix and SWOT matrix, the noken product development strategy consists of several good alternatives and can be adapted to the conditions at the noken craftsman to see the priority scale that has been set. Thus, on the basis of the analysis that has been carried out, the noken product development strategy can be formulated as follows :

1. Not yet promoting through mass media Promotion to disseminate information about products to the public so that people know about the product through mass media such as buying and selling merauke (facebook), radio, billboards and exhibitions.

2. Not yet designing images on noken products

The design of images on a product will attract the attention of consumers so that they become interested in buying products such as attractive images, product models, etc. 
3. Difficulty in getting raw materials

It is better for the noken craftsmen to cultivate wood trees (replanting in swamp areas) which is the raw material for noken bags, so that raw materials are still available.

4. The regional government provides freedom to develop the business. Local governments provide freedom and encourage every businessman to develop their own business.

5. The lack of development in terms of knowledge about craftsmen's technology

The noken craftsmen need to know about technology in order to keep theirselves up to the current development. Because with the existence of technology, all forms of activities carried out by craftsmen will all run easily.

Based on the IFE / EFE Matrix and SWOT matrix, the noken product development strategy consists of several good alternatives and can be adapted to the conditions at the noken craftsman to see the priority scale that has been set. Thus, on the basis of the analysis that has been carried out, the noken product development strategy can be formulated as follows:

1) Not yet promoting through mass media Promotion to disseminate information about products to the public so that people know about the product through mass media such as buying and selling merauke (facebook), radio, billboards and exhibitions.

2) Not yet designing images on noken products

The design of images on a product will attract the attention of consumers so that they become interested in buying products such as attractive images, product models, etc.

3) Difficulty in getting raw materials

It is better for the noken craftsmen to cultivate wood trees (replanting in swamp areas) which is the raw material for noken bags, so that raw materials are still available.

4) The regional government provides freedom to develop the business.

Local governments provide freedom and encourage every businessman to develop their own business.

5) The lack of development in terms of knowledge about craftsmen's technology

The noken craftsmen need to know about technology in order to keep theirselves up to the current development. Because with the existence of technology, all forms of activities carried out by craftsmen will all run easily.

\section{Conclusion}

The development strategy for a noken craftsman product must be done carefully and planned well in order to survive amidst competition. Noken craftsmen have a strong potential to sell their products really well because the the marketplace of noken is located in the border area with PNG country which have strong demands in terms of this handcrafted product. The need for a good noken development strategy starting from conducting promotions through buying and selling in Merauke, Facebook, billboards and others. An interesting design for noken products needs to be done, the need to cultivate wood trees which are the basic material for making noken products, the local government has supported craftsmen who continue to develop their businesses, noken craftsmen are expected to keep up with technology so they will no be left behind their competitors. Development must be done really well, also keep developing the ideas and innovate on noken products in order to survive in competition and can sustain the survival of craftsmen.

Based on the conclusions above, the suggestions must be corrected by the craftsmen as follows : 1) Disseminate information about products to the public so that people will get to know about the product through mass media such as buying and selling (facebook), radio, billboards and exhibitions, 2) Image design on a product will attract the attention of consumers in buying products such as noken with attractive images, product models, and others. It is better for the noken craftsmen to cultivate wood trees (replanting in swamp areas) which is the raw material for noken bags so that raw materials are still availablea, 3) Local governments provide freedom and encourage for every businessman to develop their own business, and 4) The noken craftsmen need to know about technology in order to keep theirselves up to the current development. Because with the existence of technology, all forms of activities carried out by craftsmen will all run easily. 


\section{Reference}

Baridwan, Zaki. 2008. Sistem Akuntansi Penyusunan Prosedur dan Metode. BPFE, Yogyakarta.

Assauri S. 1987. Manajemen Pemasaran; Dasar, Konsep dan Strategi.Edisi 1. Rajagrafindo Persada. Jakarta

Buchari, Alma, 2000. Manajemen Pemasaran dan Pemasaran Jasa, Alfabeta, Bandung.

Durianto, Sugiarto dan Tony Sitinjak, 2001.Strategi Menaklukkan Pasar Melalui Riset Ekuitas dan Perilaku Merek, PT. Gramedia Pustaka Utama, Jakarta.

David, Fred R., Manajemen Strategis Konsep. Jakarta: Salemba Empat, 1995

Gomulia, Budiana dan Intanie, Vera.Veraintanie. Struktur modal usaha kecil sentra kulit di Sukaregang, Garut, Bandung: Bina Ekonomi FE UNPAR, Edisi 2 Vol.15, 2011

Kajian Usaha Mikro Indonesia.Jurnal pengkajian Koperasi dan UKM Nomor 2 tahun 1-2006.

Rangkuti, Freddy. Analisis SWOT Teknik Membedah Kasus Bisnis Jakarta:Gramedia, 2001

Rosalinda, Linda. 2009. Analisis Strategi Pengembangan Usaha Sayuran Organik pada kelompok Tani Sugih Tani pada kawasan Agripolitan di Desa Karehkel, Kabupaten Bogor. Skripsi Departemen Manajemen Fakultas Ekonomi dan Manajemen. Institut Pertanian Bogot.Bogor.

Sugiyono. 2008. Metode Penelitian Kuantitatif, Kualitatif dan R \& D. Penerbit Alfabeta. Bandung 